\title{
Spesifikasi Benteng-Benteng Di Kawasan Bengkulu Pada Masa Kolonial Inggris
}

\author{
nfn. Mujib
}

Keywords: fort, sumatra, typology, identification, distribution

\section{How to Cite:}

Mujib, nfn. Spesifikasi Benteng-Benteng Di Kawasan Bengkulu Pada Masa Kolonial Inggris. Berkala Arkeologi, 15(3), 227-231. https:// doi.org/10.30883/jba.v15i3.699
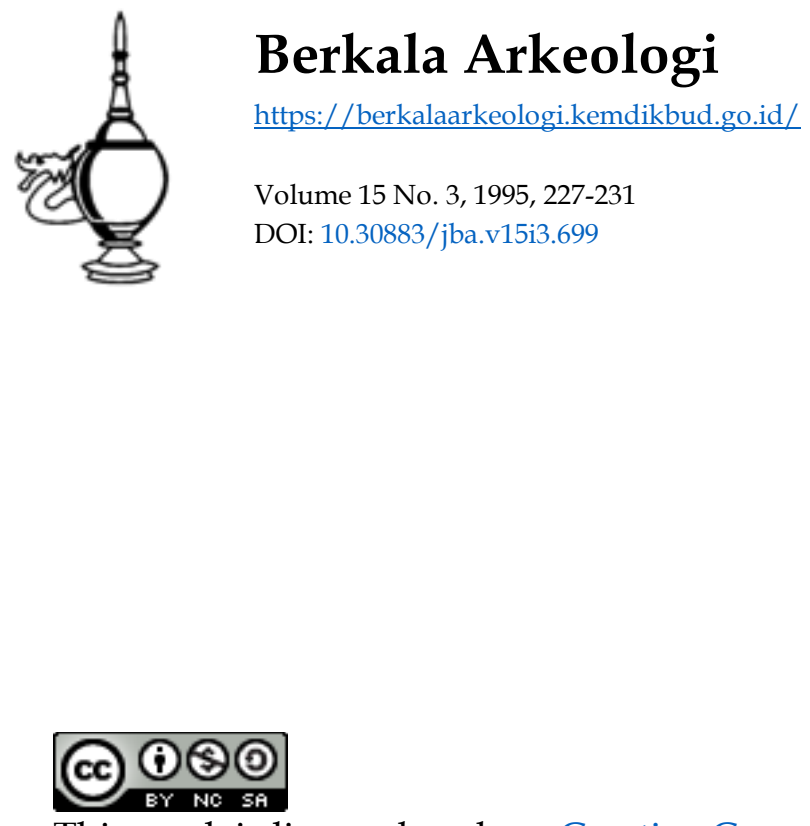

This work is licensed under a Creative Commons Attribution-NonCommercialShareAlike 4.0 International License. 


\title{
SPESIFIKASI BENTENG-BENTENG DI KAWASAN BENGKULU PADA MASA KOLONIAL INGGRIS
}

\author{
Mujib \\ (Balai Arkeologi Palembang)
}

\section{Latar Belakang}

Dalam kehidupan ini manusia membutuhkan suatu sarana dan prasaran yang dapat dipergunakan sebagai tempat berlindung dari berbagai gangguan. Mereka membuat perintang awal, te. tapi jika rintangan itu tidak efektif maka secara naluri mereka akan mempergunakan senjata alami anugerah Tuhannya yang disertakan dalam penciptaan mula seperti: sengat pada lebah, kala jengking đsb, gigi berbisa pada ular, telapak kaki belakang pada kuda dan zebra, sirip pada ikan, dan kaki-tangan pada manusia. Pada mulanya mereka menciptakan lubang-lubang dan dinding pengaman yang masih sederhana sesuai dengan kemampuan masing-masing atau menciptakan lingkungan yang memungkinkan mereka terlindung dari mara bahaya.

Manusia, makhluk yang dibekali akal dan fikiran lengkap mencoba menciptakan sarana pelindung diri yang makin lama makin berkembang sempurna dari goa, rumah yang dilengkapi pagar, tembok dan benteng. Itulah sebabnya mengapa benteng dikonotasikan oleh Weber sebagai prasarana pertahanan diri dari bahaya serangan yang mengancam (Weber, 1977 : 24). Poerwodarminto mengemukakan pengertian benteng menurut ujud fisiknya adalah 'dinding dari tembok (batu, tanah dsb) untuk melindungi kota (tempat pasukan dsb) dari serangan musuh' (Poerwodarminto,1982:121). Peristilahan benteng tidak mandeg pada pengertian fisik saja, melainkan juga merembet kepada pengertian kiasan, seperti benteng adalah 'apa saja yang dipergunakan untuk mempertahankan din dari bahaya yang mengancam dinnya' (Ibid). Pengertian kiasan yang lebih abstrak pun muncul seiring dengan kemajuan bahasa. Dalam pengertian kiasan, kata benteng dapat dipakai secara luas sesuai dengan maksud penggunanya seperti ungkapan patriotik nasionalis Indonesia: 'Pemuda adalah benteng Pancasila' atau dalam istilah keagamaan seperti ungkapan 'Iman adalah benteng jiwa manusia'. Perkembangan peristilahan inilah yang memberi dimensi baru dalam pengertian benteng di kalangan kaum moralis (pemegang teguh etika) yang mengartikan benteng dengan norma dan dogma. Kaum agamis mengartikannya dengan 'iman' (kepercayaan diri dan kepercayaan pada Tuhannya).

Uraian di atas memberikan gambaran benteng merupakan prasarana seseorang atau ke- lompok untuk mempertahankan sesuatu yang dimiliki dan diyakini kefitalan eksistensinya.

Sejak kedatangannya pertama kali di Bengkulu 24 Juni 1685 M. Inggris mengalami banyak kesulitan untuk menguasai daerah ini disebabkan ketidakfahamannya tentang adat istiadat rakyat Bengkulu (Achmaddin Dalip dkk, 1983/1984:19). Selain itu mereka ingin menerapkan sitem kekuasaannya sekehendak hati yang berbeda dengan konsepsi pemerintahan kerajaan Bengkulu

Perlawanan rakyat menentang Inggris pun meletus di mana-mana sehingga memaksa Inggris mengerahkan segala cara dan upaya untuk meredamnya, menaklukkan, dan mengontrolnya. Dibuatlah rencana besar-besaran untuk menguasai seluruh potensi daerah Bengkulu yang kaya hasil ladanya (Tim Monografi Daerah Bengkulu. 12). Seluruh potensi wilayah dipergunakan untuk mempertahankan diri dan mengamankan perdagangan lada yang menjadi tujuan utama. Didirikanlah benteng-benteng besar maupun kecil, tanah atau tembok batu-bata, sederhana atau pun sempuma. Sebagian benteng-benteng itu kini masih dapat dikenali, tetapi sebagian lagi tidak

Tulisan ini akan menguraiakn tentang spesifikasi (kekhususan, kekhasan benteng-benteng yang ada di Bengkulu seperti bentuk, letak, unsur-unsur, fungsi dan peranan) benteng di kawasan Bengkulu. Pembahasannya berdasar data-data yang diperoleh melalui kepustakaan dan laporan hasil penelitian di beberapa situs benteng di daerah Bengkulu. Data-data yang diperoleh itu kemudian diolah dengan memperbandingkan data-data yang ditemukan pada setiap benteng yang diteliti, menganalisa unsur-unsur persamaan dan perbedaannya kemudian menyimpulkan sementara dan akhirnya membuktikan melalui rangkaian keterangan yang lebih mendalam

\section{Benteng Di Kawasan Bengkulu Pada Masa Kolonial Inggris}

Penelitian terhadap situs-situs benteng $d /$ Bengkulu dilakukan oleh Pusat Penelitian Arkeologi Nasional tahun 1982,1985,1986, John Miksic mengadakan survei di Ford York tahun 1987, tim gabungan dari Pusat Penelitian Arkeologi Nasional, Direktorat Perlindungan dan Pembinaan Sejarah dan Purbakala serta Kedutaan Besar Ingris mengadakan sunei di Fort York sebagai tindak lanjut penelitian-penelitian sebelumnya. Pada tahun 1993, Balai Arkeologi Palembang dengan 
dana pembangunan mengadakan survei arkeologi islam - Kolonial di situs benteng Mukomuko, Bengkulu Uara, Suaka Peninggalan Sejarah dan Purbakala Sumbagsel mengadakan survei pendataan arkeologis di Linau dan berhasil meninjau benteng Linau. Tahun 1994 dan 1995, Balai Arkeologi Palembang dengan dana rutin dan pembangunan mengadakan survei dan ekskavasi di benteng Linau, Bengkulu Selatan.

Sejumlah penelitian di atas berhasil ditemukan pecahan keramik asing mapun lokal, serpih bilah, potongan pipa, meriam, dan beberapa benteng. Tulisan ini akan menguraikan hasil temuan secara singkat dan sebagai fokus penulisan ini adalah data benteng yang ada di Bengkulu. Arah sasaran penulisan ini adalah pengamatan unsur-unsur penting benteng dan pencarian indikasi yang berkaitan dengan judul, maka akan diuraikan masing-masing situs benteng yang dijadikan objek penelitian.

\section{A. Benteng Anna}

Benteng ini terletak di sebelah beratdaya ibukota kecamatan Mukomuko Utara, secara administratif termasuk wilayah desa Kota Jaya, keIurahan Pasar Mukomuko. Menurut beberapa sumber benteng ini dibangun pada tahun 1798 oieh Carmiel

Perlu dicatat benteng ini ditemukan dengan kondisi berupa tiga sisa potongan tembok utara sepanjang 15 meter, tepi sungai, tinggi benteng 3 $\mathrm{m}$ dan ketebalannya $2,5 \mathrm{~m}$. Sisa lorong (terowongan) setinggi $2,5 \mathrm{~m}$ sepanjang $5,5 \mathrm{~m}$ dan dua buah meriam dengan panjang $2.90 \mathrm{~m}$ dan larasnya becdiameter $11 \mathrm{~cm}$ (Koestoro,LP, dan RM Susanto.1983:21-25).

\section{B. Benteng Victory}

Ada dua sisa benteng yang masih sulit ditentukan, manakah diantara keduanya yang merupakan benteng Victory dan apa nama sisa benteng yang lainnya. Secara pasti sisa benteng yang satu terletak di pinggir alun-alun Merdeka, Mukomuko sebelah utara, di areal yang telah dipakai rumah penduduk dan bangunan lain. Denahnya tidak ketahuan lagi. Benteng itu sudah dibuat dengan batu bata dan lepa yang melingkupi areal tidak kurang dari 50 × 60 × m. Sedangkan satunya lagi terletak di sebelah timur alun-alun dekat kantor Koramil Mukomuko Utara.

Kedua benteng itu terletak di dekat sungai Selagan yang berjarak $\pm 150 \mathrm{~m}$. Pada benteng itu ditemukan meriam yang masing-masing berukuran panjang berkisar antara 2.5-3 m (Lucas PK., RM Susanto, 1993:21-25).

\section{Benteng (Fort) York}

Benteng ini terletak di dekat kuala Sungai Bengkulu pada tanah berketinggian $\pm 10 \mathrm{~m}$ dpl. Secara administratif benteng ini termasuk wilayah Kotamadya Bengkulu. Benteng ini telah dihuni sejak tahun 1685-1714. Denah bangunannya tidak diketahui lagi apalagi luasnya, hanya sisa-sisa dindingnya saja yang ditemukan terbuat dari batu bata dan lepa. Sebelah timur masih dapat dikenali bekas bastion yang merupakan salah satu unsur benteng (Tim Penelitian Fort York. 1985: 45-47).

\section{Benteng (Fort) Malborough}

Benteng ini terletak di Tapak Padera, desa Kampung, Kodya Bengkulu di tepi pantai laut teluk Bengkulu. Benteng ini terletak pada dataran berketinggian $\pm 10 \mathrm{~m}$ dpl. Benteng ini dibangun pada tahun 1714 saat Bengkulu diperintah oleh Gubernur Inggris, Joseph Collet, dikelilingi oleh tembok-tembok kokoh dengan 4 buah bastion yang terletak di masing-masing sudutnya. Pada sisi selatan, belakang gerbang masuk benteng sisi timur dan utara terdapat kolam buatan yang sangat dalam, sisi barat merupakan tepian laut teluk Bengkulu. Menurut catatan sejarah benteng ini diperkuat dengan meriam berjumiah 72 pucuk (Acmadin,Dalip,dkk,1983/1984:21-23) yang sebagiannya sampai kini masih dapat disaksikan.

\section{E. Benteng Linau}

Benteng tanah ini terletak di atas bukit Pematang Linau berketinggian $150 \mathrm{~m}$ dpl. Jarak dari pantai teluk Linau $\pm 300 \mathrm{~m}$. Secara administratif benteng ini termasuk wilayah Desa Linau. Kecamatan Perwakilan Linau, Bengkulu Selatan. Benteng ini masih utuh dengan 2 bastian dan 4 sisi dinding tanah ini dikelilingi oleh parit buatan yang berkedalaman rata-rata $3 \mathrm{~m}$. Sekelilingnya merupakan hutan dan semak belukar. Pada bastion sebelah selatan dahulunya terdapat meriam yang sekarang dipajang di depan Kantor Koramil Bintuhan, ibu kota kecamatan Kaur Selatan Benteng ini berukuran $32 \times 34$ m (Tim Penelitian Balai Arkeologi Palembang, 1994:1-2).

\section{F. Benteng Muara Sambat}

Sesuai namanya, benteng ini terletak di pinggir muara sungai Sambat dan tepi laut teluk Linau. Secara administratif benteng ini masuk wilayah Desa Parda Suka, Kecamatan Perwakiłan Linau, Bengkulu Selatan. Benteng ini tampak adanya 2 buah bastion di sudut baratdaya dan tenggara serta dinding tanah sebelah selatan yang berketinggian $3 \mathrm{~m}$ dan tebal $2 \mathrm{~m}$ serta parit buatan di luar dinding itu dengan kedalaman $3 \mathrm{~m}$ sepanjang $40 \mathrm{~m}$. 
Luas bangunan benteng ini belum diketahui, mengingat sisi-sisinya sudah tidak tampak lagi, kecuali sisi selatan. Tidak terdapat tandatanda khusus, namun sebelah barat benteng merupakan tebing yang curam dan dalam (Tim Penelitian Balai Arkeologi Palembang, 1995: 5).

\section{Rumusan Masalah}

Uraian tersebut di atas dapat dirumuskan sbb: lokasi seluruh benteng terletak di kawasan pantai atau dekat dengan pantai, kecuali benteng Linau dan Malborough terletak dekat sungai. Secara administratif benteng-benteng tersebut terietak di tiga bagian wilayah: Benteng $A$ dan $B$ di Bengkulu Utara, tepatnya mewakili sifat benteng daerah dan terletak di kawasan perbatasan antara Bengkulu dengan Sumatera Barat. Benteng C dan $D$ merupakan ujud dan manifestasi benteng perkotaan, terletak di centra kota Bengkulu dan benteng $E$ dan Fmerupakan benteng bersifat daerah, terletak di desa Linau, Kaur Selatan, Bengkulu Selatan yang merupakan wilayah perbatasan antara Bengkulu dengan Lampung.

Bentuk benteng. menunjukkan indikasi berdenah segi empat sesuai dengan temuan-temuan struktur batu bata yang berhasil ditampakkan seperti di Fort York, atau yang didapatkan sewaktu survei di benteng Anna dan Victory walaupun pada kedua lokasi ke-2 benteng terakhir itu masih sulit disimpulkan bahwa benteng-benteng tersebut berdenah segi empat. Sedang bentengbenteng yang lain seperti Malborough, Linau dan Muara Sambat dapat dipastikan berdenah segi empat.

Unsur-unsur dinding benteng menunjukkan berdinding miring ataupun tegak, terbuat dari batu-bata seperti pada benteng A, B, C dan D atau pun tanah seperti benteng $E$ dan $F$. Begitu juga bastion, seluruh benteng mempunyai unsur bastion, kecuali pada benteng Anna dan Victory yang sampai kini belum kelihatan tanda-tanda adanya bastion tersebut. Namun tidak menutup kemungkinan akan ditemukannya bastion itu pada waktuwaktu mendatang, mengingat di lokasinya terdapat beberapa pucuk meriam. Sebagaimana diketahui teori yang ada menyebutkan bahwa meriam biasanya ditempatkan pada tempat yang tinggi itu dapat dibenarkan

Unsur kolam hampir terdapat pada seluruh benteng tersebut. Seandainya tidak, toh sudah terwakili oleh sungai atau laut seperti yang terdapat pada benteng York, Anna dan Victory dimana di dekatnya mengalir sungai, sebab kolam berfungsi sebagai tempat menggenangkan air dan sama fungsinya dengan kolam buatan pada benteng, bahkan mempunyai nilai lebih.
Unsur meriam juga terdapat pada benteng $A, B, D$ dan $E$. Sedang pada benteng $C$ dan $F t_{1-}$ dak ditemukan. Namun bisa saja terdapat meriam, sebab indikasi adanya bastion merupakan tempat meriam atau sebaliknya, meriam diletakkan pada bastion.

Dari sini dapat dirumuskan bahwa bentengbenteng di kawasan Bengkulu berbentuk/berdenah segi empat, terletak di centra kota dan di daerah perbatasan, di tepi pantai atau sungai yang dapat diarungi kapal, berdinding tembok atau tanah, di sekelilingnya terdapat kolam / tempat air, tetapi bisa juga sungai atau laut, berbastion sebagai tempat pengintaian dan penempatan meriam atau senjata berat lain dan terdapat meriam sebagai senjata pengaman

Dari uraian di atas dapat dirumuskan rmasalah yang muncul: "bagaimana spesifikası benteng-benteng di Bengkulu dari segi bentuk, letak fungsi, unsur dan peranan benteng itu" ?

\section{Spesifikasi Benteng \\ 1. Bentuk}

Bentuk benteng bermacam-macam ada yang memanjang seperti benteng di Cina yang terkenal dengan tembok Besar Cina (Lois Ma'luf. 1987: 351) walaupun setiap kota di Cina menurut Weber dikelilingi tembok yang besar (Weber. 1977:23) tidak membentuk suatu lingkaran; dan benteng tanah di Bangka (Endang Sri Hardiyati. 1992). Ada pula yang berbentuk persegi panjang seperti Benteng Kuto Besak di Palembang (Djohan Hanafiah,1989:3-9), bahkan ada pula benteng yang berbentuk bulat seperti Coliseum Roma (Lois Ma'luf, 1987:480-481). Tetapi Inggris membangun benteng-benteng di Bengkulu dalam bentuk empat persegi.

\section{Letak}

Tidak satu benteng pun yang dibangun koionial Inggris diletakkan di daerah pegunungan walaupun itu berbatasan dengan wilayah kekuasaan Belanda dan raja-raja yang menjadi saingannya. Hal itu karena kawasan pegunungan pada masa itu sudah merupakan benteng alam yang sulit ditembus dan dilalui oleh musuh mengingat hutannya lebat dan daerahnya curam.

Melihat penempatan benteng-benteng di daerah, seperti Mukomuko dan Linau bahkan di Bengkulu menunjukkan adanya fungsi Iain. Di daerah perbatasan misalnya, benteng di samping berfungsi sebagai prasarana pertahanan, juga berfungsi sebagai basis tempat pengawasan petani yang menanam tanaman komodite perdagangan seperti lada. Sedang benteng Malborough di kota Bengkulu berfungsi sebagai penjara bagi pribumi atau siapa saja yang membangkang dan 
melawan Inggris mengingat di dalam benteng tersebut terdapat ruang-ruang berterali. Perlu dipertanyakan, apakah ruang-ruang dan terali itu dibuat oleh Inggris atau Belanda yang berkuasa sesudahnya?. Disamping itu benteng ini juga berfungsi sebagai tempat penyelenggaraan administrasi perdagangan dan pengiriman hasil-hasil komudite perdagangan serta sebagai centra komando keamanan.

Di samping itu benteng-benteng di Bengkulu juga berfungsi sebagai tempat pengawasan dan pengamanan jalur pelayaran di laut dan pengamanan bandar-bandar perdagangan yang terdapat dekat benteng mengingat seluruh bentengbenteng itu terletak di tepi pantai.

\section{Unsur}

Unsur-unsur yang terdapat pada setiap benteng di Bengkulu seperti dinding tembok atau tanah untuk menghambat musuh agar mereka tidak mudah menuju langsung ke sasaran yang diinginkan. Bastion yang bertempat tinggi dipergunakan untuk pengintaian dan penempatan senjata yang dapat ditembakkan untuk menghalau dan memusnahkan musuh, kolam/parit dipergunakan untuk menghambat musuh yang ingin masuk ke benteng karena dengan lumpur kolam/parit itu siapapun akan kesulitan memanjat dinding benteng. senjata meriam sewaktu-waktu dapat dipergunakan untuk menembak musuh. Unsur-unsur itu dapat membantu kita memprediksikan dan mengasumsikan benteng-benteng berfungsi sebagai prasarana pertahanan, sebab unsur-unsur di atas itulah yang mendukung mengapa benteng itu difungsikan sebagai prasarana pertahanan (Novida Abbas, 1985:607; Bambang Budi Utomo dan Djohan hanafiah, 1993:B3-3).

\section{Fungsi}

Fungsi benteng beragam, disamping sebagai prasarana pertahanan benteng juga berfungsi sebagai batas wilayah kekuasaan seperti tembok benteng Cina pada masa awal keberadaannya merupakan batas hunian pemukiman raja, kaum kerabat, dan pelaksana pemerintahan seperti kaum agamis dengan masyarakat luas (Bambang Budi Utomo dan Djohan Hanafiah, 1993:B3-3). Benteng-benteng kolonial Inggris ini mempunyai kekhususan fungsi yang berbeda, yaitu sebagai prasaran pertahanan dan prasarana pengontrolan keamanan di wilayah sekitar benteng, bukan sebagai tempat hunian.

Patut dicatat benteng-benteng Inggris di Bengkulu bukanlah merupakan benteng hunian masyarakat elite politis seperti lazimnya bentengbenteng kerajaan-kerajaan Islam - di Nusantara - yang luasnya mencapai ukuran tidak kurang darı $200 \times 200 \mathrm{~m}$

\section{Peranan}

Peranan benteng-benteng di Bengkulu bagi kolonial Inggris dapat dikaji melalui penempatannya yang merata di kawasan pantai Bengkulu dan temuan-temuannya yang beraneka ragam serta unsur-unsur lain yang terdapat di dalam benteng itu dan manusianya (dalam hal ini pasukan). Sebab kenyataannya keberadaan benteng tidak berperan kecuali dengan pasukannya

Keletakan dan penempatan benteng-benteng di tepi pantai barat Sumatera yang strategis bagi pelayaran tampaknya berperan sebagaı penghubung antar bandar dan pelabuhan yang terdapat di dekatnya dengan benteng lain guna mengkoordinir kegiatan perdagangan yang berpusat di Fort kemudian dipindahkan ke Fort Malborough. Benteng-benteng daerah perbatasan berperan sebagai 'basic to open regions' di sekitarnya bagi kepentingan pengumpulan hasi-hasil pertanian perdagangan. Selain itu benteng berperan sebagai 'support of Troops' yang sewaktuwaktu dibutuhkan dapat mempertahankan wilayah yang dikuasainya. Seluruh benteng itu berperan sebagai tempat pengkoordinasian dan penetratisiran keamanan kawasan di sekitarnya yang kemudian dikomunikasikan melalui informasi laut dengan kapal yang menghubungkan antar bandar di pantai Bengkulu.

Sistem perhubungan laut di Bengkuiu memungkinkan adanya bandar-bandar yang perlu pengawasan dan pengamanan yang memadai Untuk itulah benteng-benteng di Bengkulu dibangun dekat dengan pelabuhan dan bandar. Hal inı memerlukan peran benteng-benteng demi keamanan lingkungan beserta pasukannya

Jadi benteng secara terpisah merupakan sistem yang berperan dalam pertahanan dan pengamanan lingkungannya. Secara luas dan jamak bertalian dengan sistem pertahanan dan pengamanan regional Bengkulu yang merupakan wilayah kekuasaan Inggris yang berpusat di Fort Malborough. Pusat pengkoordinasian keamanan menyeluruh bagi kelangsungan kekuasannya.

Benteng-benteng di daerah dan di perbata. san wilayah berperan sebagai mata rantai pelaksana perintah benteng pusat. Peran itu berupa memata-matai dan mengawasi gerak gerik musuh yang mengancam keselamatan dan keamanannya. Sedangkan benteng pusat memberikan komando masalah keamanan lingkungan wilayah kekuasaannya. Inilah sebabnya mengapa sistem pertahanan benteng ini merupakan kesatuan utuh dan merupakan sistem yang diciptakan Inggris untuk kelangsungan kekuasaannya. 


\section{Penutup}

Bengkulu sebagi salah satu penghasil lada terbesar di Nusantara dikuasai Inggris sejak 1685 -1825 (Achmadin Dalip,dkk: 19-40). Untuk kelangsungan kekuasaan dan keamanan lingkungannya maka dibutuhkan sumberdaya manusia berupa pasukan, dan sumberdaya lain seperti sumberdaya alam dan personalia keamanan, sarana dan prasarana pertahanan-keamanan. Benteng-benteng dibangun berdenah empat persegi berlokasi di tempat-tempat yang dianggap strategis dengan dilengkapi peralatan-peralatan, unsur-unsur yang memadahi (ruang berterali untuk penjara, dinding tegak atau miring dari batu bata atau tanah sebagai pelindung. kolam-kolam atau genangan-genangan air buatan atau alami untuk menghambat gerak laju musuh memasuki benteng, bastion untuk pengintipan dan penempatan meriam dan alatalat pertahanan lainnya).

Benteng-benteng yang dibangun itu bukan berfungsı sebagai tempat hunian kaum elite politik melainkan berfungsi sebagai prasarana pertahanan-keamanan dan kelangsungan dagang.

Dalam kaitannya dengan keamanan, ekonomi, dan kekuasaan, benteng berperan sebagai penghubung antar satuan-satuan keamanan. Secara terpisah benteng berperan sebagai pengawas daerah sektitarnya. Laut memegang peranan sebagai jalan utama yang menghubungkan bandar-bandar demi kelancaran angkutan hasil pertanian yang dijadikan komudite perdagangan.

Keutamaan benteng diprogram sebagai sistem pertahanan Inggris di Bengkulu dengan satuan tugas masing-masing benteng disesuaikan dengan tempat dan lokasinya.

\section{KEPUSTAKAAN}

Abbas,Novida. 1985. Biting, Suatu Studi Pendahuluan Tentang Unsur Pertahanan, REHPA II, Jakarta:Puslit Arkenas.

1988. Kerangka Teori Penelitian Situs Biting, REHPA III. Jakarta:Depdikbud.

Dalip,Achmadin,dkk.1983/84. Sejarah Perlawanan Terhadap Imperialisme dan Kolonialisme di Daerah Bengkulu, Bengkulu:Proyek Inventarisasi dan Dokumentasi Sejarah Nasional.

Hardiyati,Endang Sri.1982. Laporan Survei Arkeologi di Bangka dan Belitung.
Kartodirjo,Sartono(ed).1977. Masyarakal Kuno dan Kelompok-Kelompok Sosial, Jakarta Bhrarata Karya Aksara.

Koestoro,Lucas Partanda \& RM. Soesanto. 1993 Laporan Hasil Penelitian Arkeologi Sur. vei Arkeologi Bengkulu Palembang:Balai Arkeologi Palembang, bt

Ma'luf,Lois.1986. Al-Munjid fi-l Lugah, Beirut: Darul Masyrik

1987. Al-Munjid fi-l 'A'lam, Beirut: Darul Masyrik.

Susana, Astrid S.1985. Pengantar Sosiologi Perubahan Sosial, Bina Cipta.

Tjandrasasmita,Uka(ed).,1975. Sejarah Nasional Indonesia jilid III, Jakarta: Balai Pustaka

Tim Peneliti Balai Arkeologi Palembang.1994 Laporan Survei dan Ekskavasi Benteng Linau, Bengkulu Selatan Palembang:Bala Arkeologi Palembang. bt.

1995. Laporan Penelitian Benteng Linau, Palembang Palembang Paleríbang: Bala Arkeologi Palembang, bt.

Tim Penelitlan Fort York. 1988. Laporan Penelitian Arkeologi Fort York Bengkulu Jakarta Puslit Arkenas, bt.

Weber.Max.1977.Apakah yang Disebut Kota? dalam Masyarakat Kota dan KelompokKelompok Sosial, Sartono Kartodirdjo (eđ) Jakarta: Bhratara Karya Aksara.

Utomo,Bambang Budi \& Djohan Hanaflyah 1993 Palembang Masa Masca Sriwijaya dalam Sriwijaya Dalam Perspektif Arkeologi dan Sejarah Palembang:Pemda Tk. I Sumatera Selatan. 


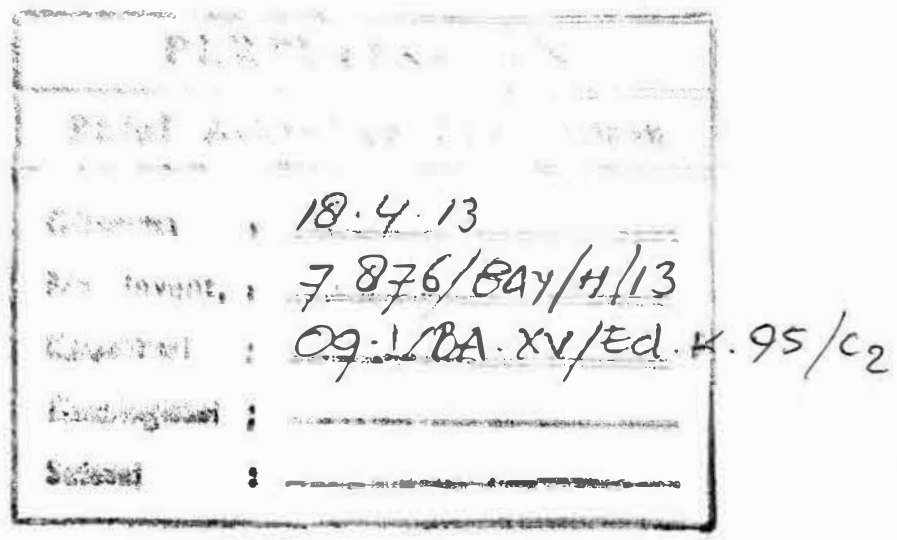

